NASA/TM-2010-216742

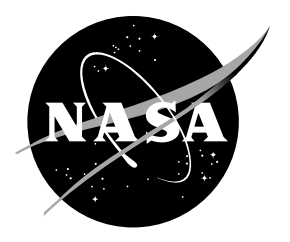

\title{
Design of a Facility to Test the Advanced Stirling Radioisotope Generator Engineering Unit
}

Edward J. Lewandowski, Jeffrey G. Schreiber, and Salvatore M. Oriti Glenn Research Center, Cleveland, Ohio

David W. Meer

Sest, Inc., Middleburg Heights, Ohio

Michael H. Brace and Gina Dugala

Glenn Research Center, Cleveland, Ohio 


\section{NASA STI Program . . . in Profile}

Since its founding, NASA has been dedicated to the advancement of aeronautics and space science. The NASA Scientific and Technical Information (STI) program plays a key part in helping NASA maintain this important role.

The NASA STI Program operates under the auspices of the Agency Chief Information Officer. It collects, organizes, provides for archiving, and disseminates NASA's STI. The NASA STI program provides access to the NASA Aeronautics and Space Database and its public interface, the NASA Technical Reports Server, thus providing one of the largest collections of aeronautical and space science STI in the world. Results are published in both non-NASA channels and by NASA in the NASA STI Report Series, which includes the following report types:

- TECHNICAL PUBLICATION. Reports of completed research or a major significant phase of research that present the results of NASA programs and include extensive data or theoretical analysis. Includes compilations of significant scientific and technical data and information deemed to be of continuing reference value. NASA counterpart of peer-reviewed formal professional papers but has less stringent limitations on manuscript length and extent of graphic presentations.

- TECHNICAL MEMORANDUM. Scientific and technical findings that are preliminary or of specialized interest, e.g., quick release reports, working papers, and bibliographies that contain minimal annotation. Does not contain extensive analysis.

- CONTRACTOR REPORT. Scientific and technical findings by NASA-sponsored contractors and grantees.
- CONFERENCE PUBLICATION. Collected papers from scientific and technical conferences, symposia, seminars, or other meetings sponsored or cosponsored by NASA.

- SPECIAL PUBLICATION. Scientific, technical, or historical information from NASA programs, projects, and missions, often concerned with subjects having substantial public interest.

- TECHNICAL TRANSLATION. Englishlanguage translations of foreign scientific and technical material pertinent to NASA's mission.

Specialized services also include creating custom thesauri, building customized databases, organizing and publishing research results.

For more information about the NASA STI program, see the following:

- Access the NASA STI program home page at http://www.sti.nasa.gov

- E-mail your question via the Internet to help@ sti.nasa.gov

- Fax your question to the NASA STI Help Desk at $443-757-5803$

- Telephone the NASA STI Help Desk at 443-757-5802

- Write to: NASA Center for AeroSpace Information (CASI) 7115 Standard Drive Hanover, MD 21076-1320 
NASA/TM-2010-216742

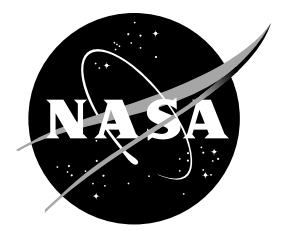

\section{Design of a Facility to Test the Advanced Stirling Radioisotope Generator Engineering Unit}

Edward J. Lewandowski, Jeffrey G. Schreiber, and Salvatore M. Oriti

Glenn Research Center, Cleveland, Ohio

David W. Meer

Sest, Inc., Middleburg Heights, Ohio

Michael H. Brace and Gina Dugala

Glenn Research Center, Cleveland, Ohio

Prepared for the

Seventh International Energy Conversion Engineering Conference (IECEC)

sponsored by the American Institute of Aeronautics and Astronautics

Denver, Colorado, August 2-5, 2009

National Aeronautics and

Space Administration

Glenn Research Center

Cleveland, Ohio 44135 


\section{Acknowledgments}

This work is funded through the NASA Science Mission Directorate. Any opinions, findings, conclusions, or recommendations expressed in this article are those of the authors and do not necessarily reflect the views of the National Aeronautics and Space Administration. The authors wish to acknowledge the many people who supported the design and build-up of the Advanced Stirling Radioisotope Generator (ASRG) Engineering Unit (EU) test facility in the Stirling Research Laboratory at the NASA Glenn Research Center, including those at Lockheed Martin in Valley Forge and Denver who guided us in Advanced Stirling ASRG EU control and operation.

This report contains preliminary findings, subject to revision as analysis proceeds.

Trade names and trademarks are used in this report for identification only. Their usage does not constitute an official endorsement, either expressed or implied, by the National Aeronautics and Space Administration.

Level of Review: This material has been technically reviewed by technical management.

Available from

NASA Center for Aerospace Information 7115 Standard Drive

Hanover, MD 21076-1320
National Technical Information Service 5301 Shawnee Road Alexandria, VA 22312 


\title{
Design of a Facility to Test the Advanced Stirling Radioisotope Generator Engineering Unit
}

\author{
Edward J. Lewandowski, Jeffrey G. Schreiber, and Salvatore M. Oriti \\ National Aeronautics and Space Administration \\ Glenn Research Center \\ Cleveland, Ohio 44135 \\ David W. Meer \\ Sest, Inc. \\ Middleburg Heights, Ohio 44130 \\ Michael H. Brace and Gina Dugala \\ National Aeronautics and Space Administration \\ Glenn Research Center \\ Cleveland, Ohio 44135
}

\begin{abstract}
The Advanced Stirling Radioisotope Generator (ASRG), a high efficiency generator, is being considered for space missions. An engineering unit, the ASRG engineering unit (EU), was designed and fabricated by Lockheed Martin under contract to the Department of Energy. This unit is currently under extended operation test at the NASA Glenn Research Center (GRC) to generate performance data and validate the life and reliability predictions for the generator and the Stirling convertors.

A special test facility was designed and built for the ASRG EU. This paper summarizes details of the test facility design, including the mechanical mounting, heat-rejection system, argon system, control systems, and maintenance. The effort proceeded from requirements definition through design, analysis, build, and test. Initial testing and facility performance results are discussed.
\end{abstract}

\section{Nomenclature}

$\begin{array}{ll}\text { ACU } & \text { ASC Control Unit } \\ \text { ASC } & \text { Advanced Stirling Convertor } \\ \text { ASRG EU } & \begin{array}{l}\text { Advanced Stirling Radioisotope Generator Engineering Unit } \\ \text { cold-side adapter flange } \\ \text { CSAF }\end{array} \\ \text { electric heat source } \\ \text { GPHS } & \text { General Purpose Heat Source } \\ \text { GRC } & \text { Glenn Research Center } \\ \text { LM } & \text { Lockheed Martin } \\ \text { NASA } & \text { National Aeronautics and Space Administration } \\ \text { UPS } & \text { uninterruptible power supply }\end{array}$

\section{Introduction}

The Advanced Stirling Radioisotope Generator (ASRG) is a high-efficiency generator being developed for potential use on space missions. The ASRG system efficiency of 28 to 32 percent would reduce the amount of radioisotope required for a given power level by a factor of four in comparison to that for radioisotope thermoelectric generators. Its high specific power (7 We/kg or greater (Ref. 1)) enables certain missions and applications. 
A key step in the flight development process was the design and fabrication of an ASRG engineering unit (EU), by system integrator Lockheed Martin Space Systems Company (LM) under contract to the Department of Energy (Ref. 1). The generator assembly was completed in December 2007 and controller integration followed in March 2008. This unit underwent a series of system-level tests to qualification level thermal and dynamic environments at LM. These included thermal balance, thermal performance, mechanical disturbance, sine transient, random vibration, simulated pyrotechnic shock, and electromagnetic interference (Ref. 2). Following an internal inspection, LM delivered the ASRG EU to the NASA Glenn Research Center (GRC) on August 28, 2008, for extended operation. The EU underwent inspection followed by integration into a test facility specially designed for the EU. The ASRG EU began extended operation on November 6, 2008. This test is intended to demonstrate extended operation of an integrated system, to monitor for trends in Stirling convertor performance, and to provide additional data from long-term operation of Stirling convertors. The EU has operated almost 5,000 hr to date at NASA GRC (Ref. 3).

This paper discusses details of the test facility design and highlights the special features incorporated for the ASRG EU. The design leveraged years of GRC experience in testing Stirling convertors in dualopposed pairs. The EU is the first Stirling generator system tested at GRC that has an integrated heat source, insulation, sealed housing, and controller. Special consideration was made for the mounting, heat rejection, argon system, controller, and other aspects of the facility.

\section{The ASRG EU}

Figure 1 shows a cutaway model of the ASRG EU. The EU contains two Advanced Stirling Convertor (ASC)-E convertors secured together through an interconnect sleeve. An electric heat source (EHS), held against each ASC-E heat collector, provides the heat input. The cold-side adapter flanges (CSAFs) conduct heat rejected from the convertors away through the beryllium housing and fins, to be then radiated away in a vacuum environment or convected to air. Argon fills the housing, sealed using various O-rings and gaskets. A gas management valve allows access to the argon. The controller is mounted to the outside of the housing. Connectors on the end enclosures, housing, and controller provide electrical interfaces to the alternators, sensors, power input and output, control, and telemetry. The EU is mounted via four mounting tabs on one end of the housing, bolting to a spacecraft interface or directly to its support.

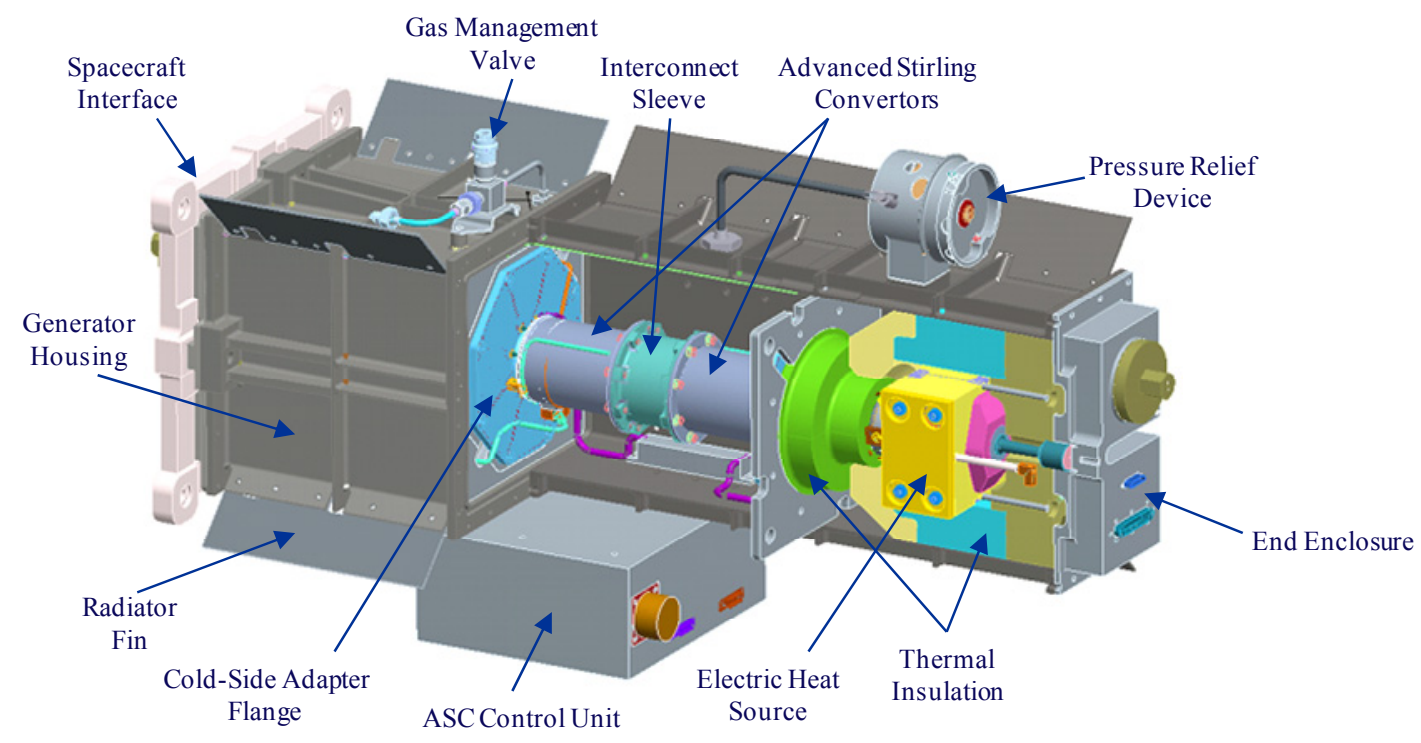

Figure 1.-ASRG EU cutaway model. 


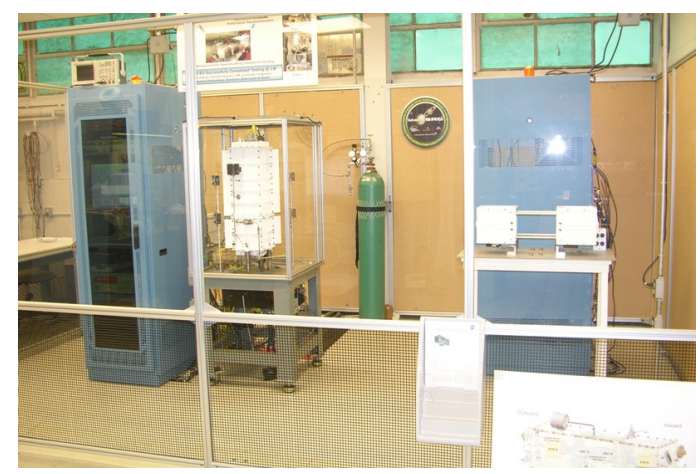

Figure 2.-ASRG EU test facility.

Figure 2 shows the test facility. The ASRG EU is mounted on a test table through stand-offs and is surrounded by a Lexan cage. Ductwork, fans, heat exchangers, and plumbing to a circulator (not shown) for cooling all reside underneath the table. The test rack, which contains the power supplies, the instrumentation, the computer, and the data acquisition, control, and monitoring system, is placed to the left of the test table. An argon cylinder and associated gas management hardware is mounted behind the test table. Framed Lexan partitions surround the test facility. A facility to test two ASC-E convertors can be seen in the right half of the partitioned area.

\section{Test Facility Requirements}

The design process for the test facility began by defining the requirements. Although the EU could be tested in a variety of ways under various operating conditions, the extended operation test as discussed in the introduction focused on 24/7 steady operation for several years. To meet cost and schedule constraints, it was important to define the functionality necessary for extended operation. As designers focused on this objective, the high-level requirements became:

- Mount in a vertical orientation, in a way that allowed monitoring of interface dynamic forces. Vertical orientation may work the convertor piston and displacer gas bearings harder. Several convertors are already under extended operation test in the horizontal orientation, so the vertical orientation expands the breadth of extended operation test conditions.

- Provide two control options: (1) alternating-current (AC) bus control, and (2) ASC Control Unit (ACU) control. The EU would begin operation under AC bus control then transition to ACU control.

- Provide two input power options for the heat source control: (1) fixed hot-end temperature mode, which has been used to date on all extended-operation convertor tests, and (2) fixed heat input mode, which simulates the General Purpose Heat Source (GPHS) module characteristics and tests the temperature-control feature of the ACU.

- Remove heat from the EU fins and housing in a way that maintains a fairly constant rejection temperature at the convertor cold end, preferably as low as $50^{\circ} \mathrm{C}$.

- Maintain argon pressure inside the EU within the required range.

- Monitor various parameters throughout the system with calibrated instrumentation, as has been done with other convertors under extended operation, and include ACU controller parameters.

- Operate 24/7 unattended, including safety systems to protect the ASRG EU in the event of an equipment failure or abnormal operation, shutting down the ASRG EU in a controlled fashion if necessary.

- Achieve high uptime (greater than 85 percent).

- Record performance data regularly.

- Display the ASRG EU in a visually attractive way for visitors but at the same time protect the unit from unauthorized activity. 


\section{Test Facility Design}

The ASRG EU test facility was based on existing extended-operation test facilities at GRC described in References 4 to 7. Although many features are common with existing facilities, the ASRG EU drove several unique features, described in detail here.

\section{Mechanical Mounting}

The ASRG EU is rigidly mounted to the test table as shown in Figure 3. The EU housing includes four mounting tabs at one end to which four standoffs are attached. These standoffs lift the EU above the test table enough to allow access to the electrical connectors on the end of the EU, and they bolt to a 3/4-in- thick steel table top, with Kistler 9251A load cells inserted between the standoffs and table top. The table top was designed per the load cell manufacturer's recommendations so that the sensors would achieve the advertised accuracy. The load cells provide dynamic measurement of the interface force produced by the EU in all three axes, although the force in the axial direction is the one generally of greatest interest. A Kistler triaxial model 8692 accelerometer is attached to one stand-off.

This test table can be adapted to transport the ASRG EU (Fig. 4). Side rails with retractable wheels and jack screws can be bolted to the side of the test stand. When the ASRG EU arrived at GRC, it was transferred from the transport container directly to the test stand, then wheeled from the loading dock into position in the test facility. From there the test table was bolted into place.

\section{Heat Rejection System}

For previous ASC in-air extended-operation convertor test at GRC, heat was removed from the coldend heat exchanger by conduction through a flange and directly to the cooling fluid. In the case of the ASRG EU, heat conducted away from the cold end of the convertor through the CSAF and into the sides of the EU housing and the fins provides the cooling mechanism. From there the heat could have been rejected either into cooling tubes attached to the fins or to the air surrounding the EU. To avoid any risk of damage or marring of the EU surface, it was decided to use the air surrounding the EU for heat rejection.

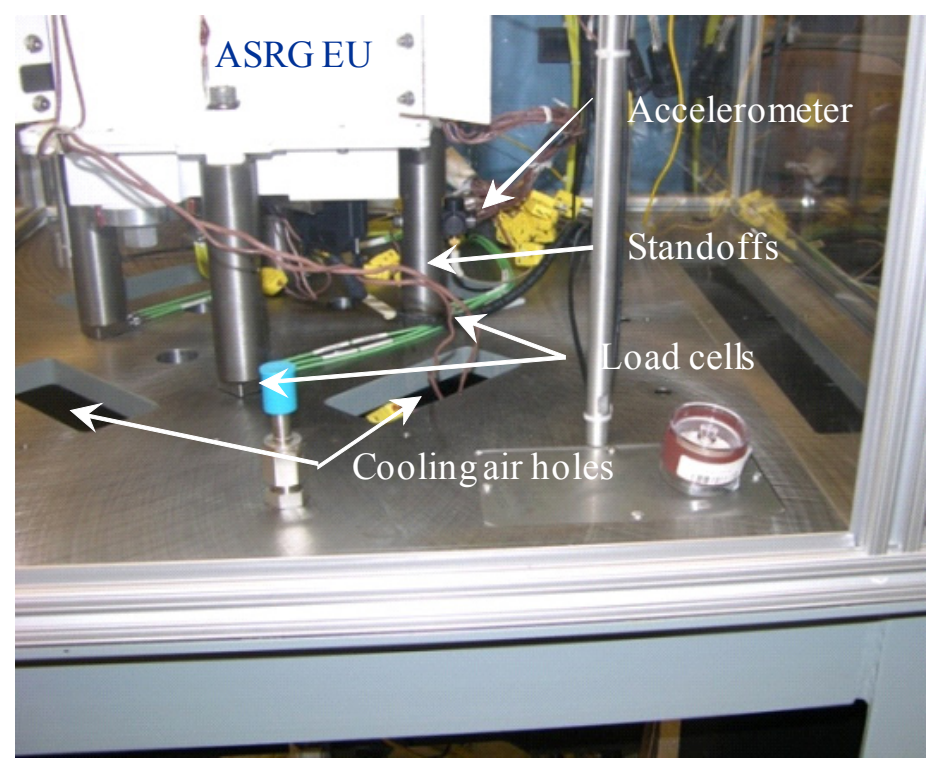

Figure 3.-ASRG EU mounting to the test table.

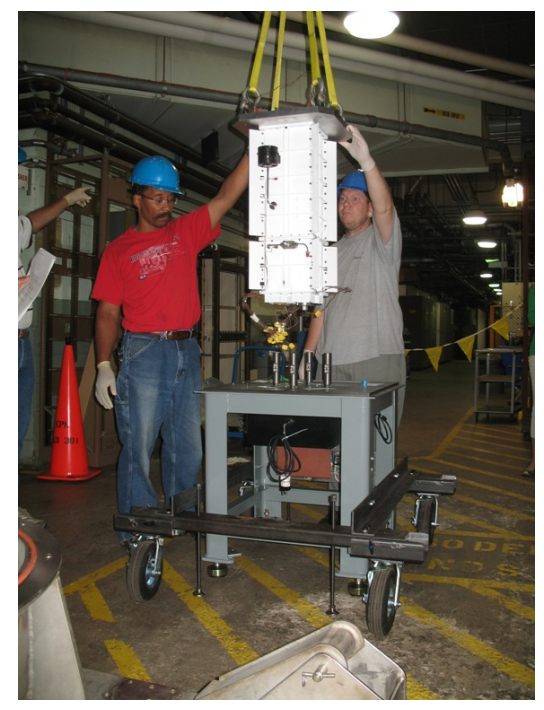

Figure 4.-Test stand transporting the ASRG EU. 
A cage made of 80/20 modular aluminum framing with Lexan sides surrounding the EU was built on top of the test table (Fig. 5). Air flows up out of cooling air holes in the test table (Fig. 3) and past the sides and fins of the EU, then it flows back down a Lexan duct to a metal duct under the table that houses a pair of fans and heat exchangers (Figs. 6 and 7). A circulator provides water chilled to $10{ }^{\circ} \mathrm{C}$ to the heat exchangers. The circulator sits just outside the partitioned area that surrounds the ASRG EU and test rack to reduce the heat load within the partitioned area.

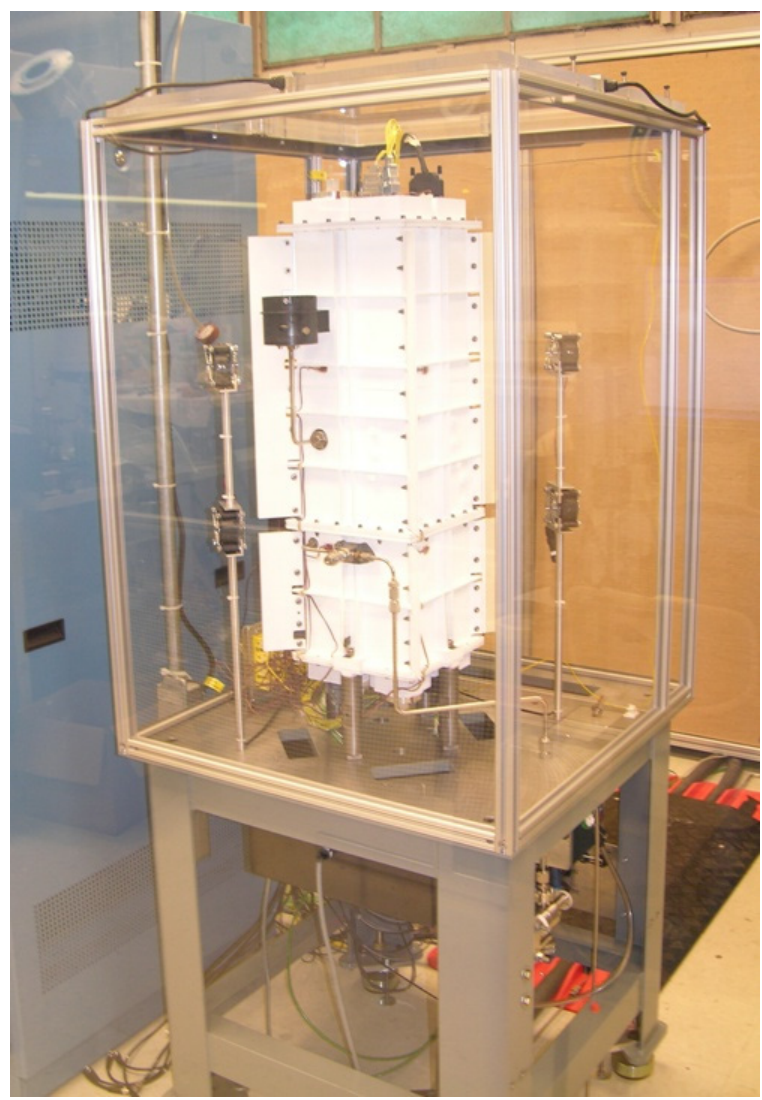

Figure 5.-ASRG EU in Lexan cage.

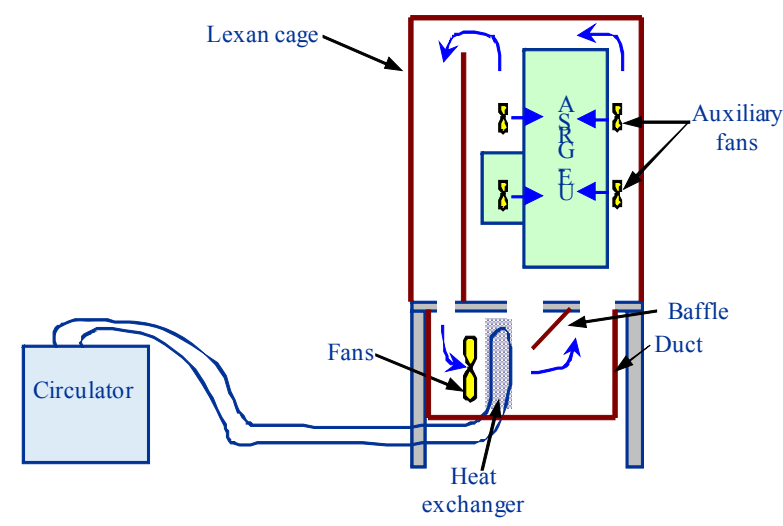

a) Normal operation.

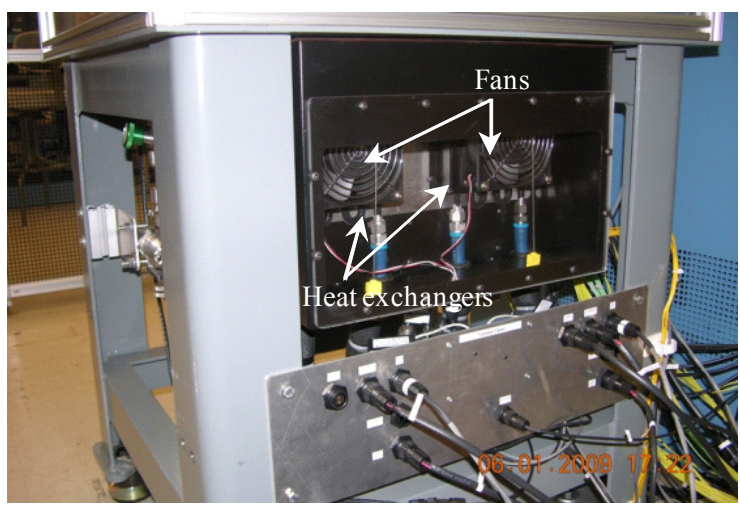

Figure 6.-Fans and heat exchangers under the test table.

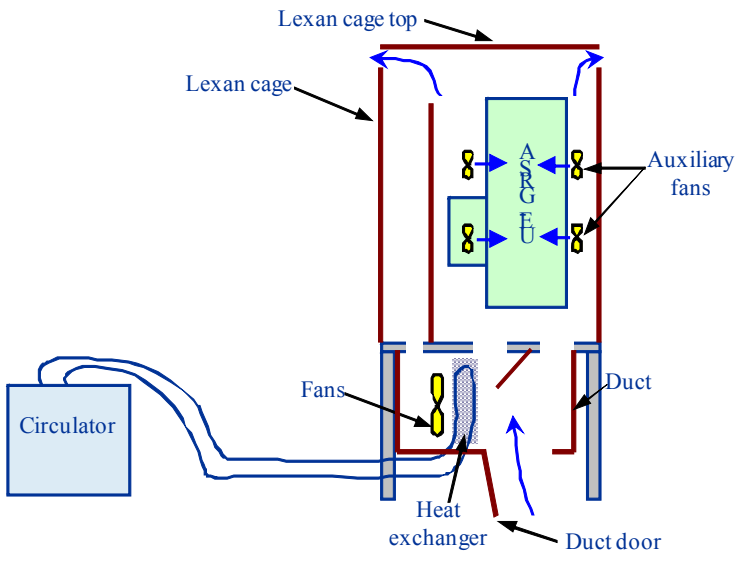

b) Emergency shutdown mode.

Figure 7.-Schematics of the heat rejection system. 
During complete loss of facility power, the system must include the capability to dissipate the stored thermal energy in the hottest internal components (e.g., heaters and heat collectors) to prevent other internal components from exceeding their allowable temperature limits during the shutdown transient. Overheating could be possible if the EU was in an enclosed chamber. Simply allowing natural convection to pull heat from the sides of the EU by venting the cage would be sufficient to keep temperatures within acceptable ranges.

As a solution, the cage was designed with a spring-loaded top and a door on the bottom, both held closed by solenoids (Fig. 7(a)). Removing power from the solenoids causes the top of the cage to pop up about $1 \mathrm{in}$. and the door on the bottom to drop open, allowing air to flow past the ASRG EU, driven by a chimney effect.

The cooling system was designed to remove the heat coming from the ASRG EU during normal operation, primarily the electrical heat input less power removed through the alternators (around $400 \mathrm{~W}$ ). The shunt resistors, internal to the EU and used only as an emergency load by the ACU, were not hooked up, and therefore the cooling system did not need to compensate for that additional load.

Prior to installation of the EU, the cooling system was tested using power resistors to simulate the heat load from the EU (Fig. 8). With an input heat load of $360 \mathrm{~W}$, the fluid temperature was set to $20^{\circ} \mathrm{C}$. A test load closer to $400 \mathrm{~W}$ would have accounted for higher insulation losses in the EU. Under these conditions, there was a $6.9{ }^{\circ} \mathrm{C}$ air temperature drop and a $0.6{ }^{\circ} \mathrm{C}$ fluid temperature drop across the heat exchangers, with the air temperature entering the ASRG cavity maintained at $23.9^{\circ} \mathrm{C}$. This test demonstrated that the system had sufficient cooling capacity to maintain a reasonable air temperature while removing the expected heat load. The only part of the heat rejection system not tested was the heat transfer from the EU housing and fins to the air.

The cooling system test included measurement of the air-flow rates through the cooling air holes in the table. The front pair of holes (farthest from the fans) had roughly twice the flow rate of the back pair of holes. To better balance the flow, a baffle was mounted under the table to increase the flow through the back holes (Fig. 7).

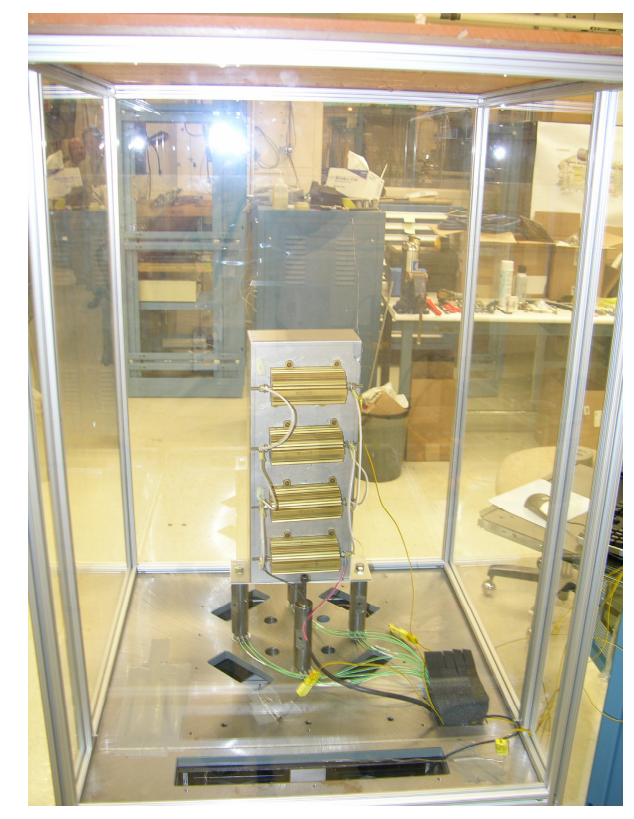

Figure 8.-Test of the heat rejection system. 


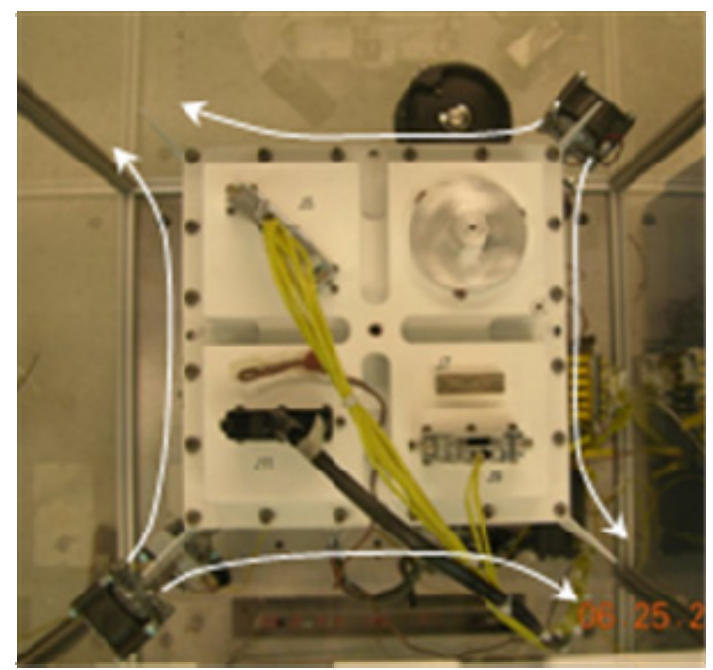

Figure 9.-Top view of ASRG EU showing the air-flow of the auxiliary fans across sides of the EU.
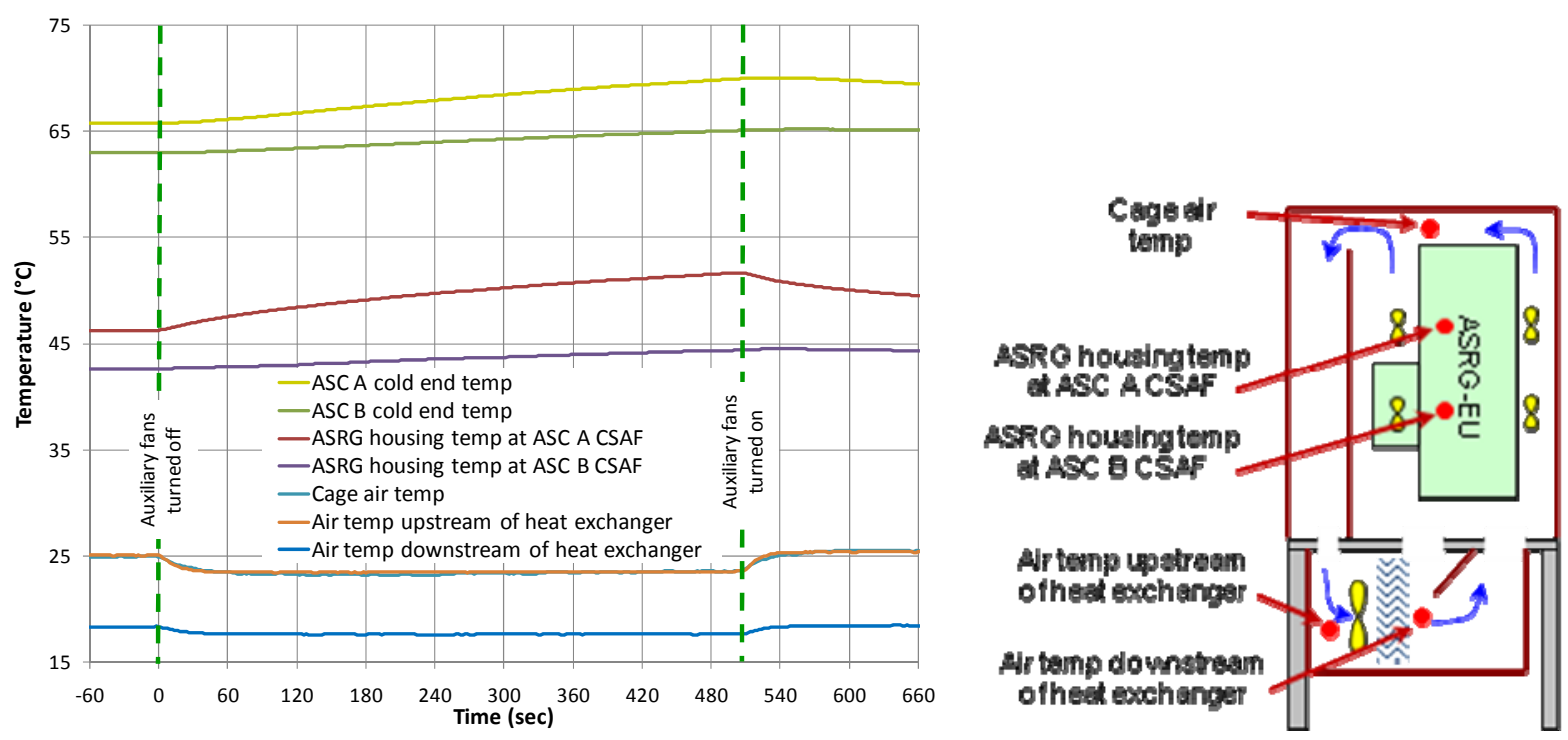

Figure 10.- Various temperatures when auxiliary fans were briefly turned off, along with a diagram showing temperature measurement locations.

As mentioned earlier, the cooling system test did not validate the heat transfer from the EU housing and fins to the air. When operating the ASRG EU in room temperature air, LM had achieved sufficient cooling by using two large fans to blow air over the ASRG EU, enhancing convective heat transfer. This test facility, with smaller fans and passages, did not produce the same high air flow past the housing. So, in addition to circulating cooler air around the EU (the air temperature would start a few degrees above the coolant temperature of $10{ }^{\circ} \mathrm{C}$ ), auxiliary fans were mounted next to the ASRG EU to blow air across the housing and fins to improve heat transfer. Note the two black fans on each side of the EU in Figure 5. Mounting the auxiliary fans diagonally across the EU allows each fan to blow air across two sides of the housing (Fig. 9). The fans were placed at elevations corresponding to the location of the CSAFs, where a majority of the rejected heat was being conducted.

During checkout of the system with the ASRG EU operating near full power, the auxiliary fans were turned off to determine how critical they were to cooling. The plots in Figure 10 show that the effect was dramatic, especially on the ASC A (top) end of the EU. When the fans stopped, the housing temperature 
rose $5{ }^{\circ} \mathrm{C}$ in $8 \mathrm{~min}$, and the temperatures had not leveled off when the fans started after about $81 / 2 \mathrm{~min}$. The air temperatures around the EU dropped, indicating decreased heat transfer to the air and that ultimately, transferring the heat rejected by the EU would require a much larger temperature difference between the air and the EU housing. This test demonstrated the criticality of the auxiliary fans to maintaining operation at the design operating conditions.

\section{Argon System}

During ground operations, an argon cover gas fills the ASRG housing to prevent oxidation of the graphitic components of the heat source. The test facility's argon system maintains pressure between 5 and 9 psig whereas the EU requires a pressure between 3.3 and 15.3 psig.

A mechanical regulator with a range of 0 to 10 psig controls this pressure. Because the EU is a closed volume, the pressure changes primarily during startup and shutdown as internal temperatures change. A small orifice placed between the pressure regulator and the EU limits the gas flow rate in the unlikely event of a regulator failure to a rate that the pressure relief valve could handle, preventing the EU from possibly being overpressurized.

The argon system includes a provision for connecting a vacuum pumping station with a residual gas analyzer. The gas in the EU is periodically monitored for the presence of air. Figure 11 shows a schematic of the argon system.

\section{Facility Electrical Power}

An uninterruptible power supply (UPS) provides backup power for the ASRG EU test facility so that a loss of building power, even momentarily, does not cause a loss of control and convertor stall. Furthermore, a 50-kW natural-gas-fueled backup generator provides power in the event of a loss of building power. In the unlikely event of loss of power from the backup generator and building power, the system will automatically shut down the ASRG EU. Power draw during shutdown is under $1500 \mathrm{VA}$, and the UPS can power the system for at least $6 \mathrm{hr}$ during a controlled shutdown.

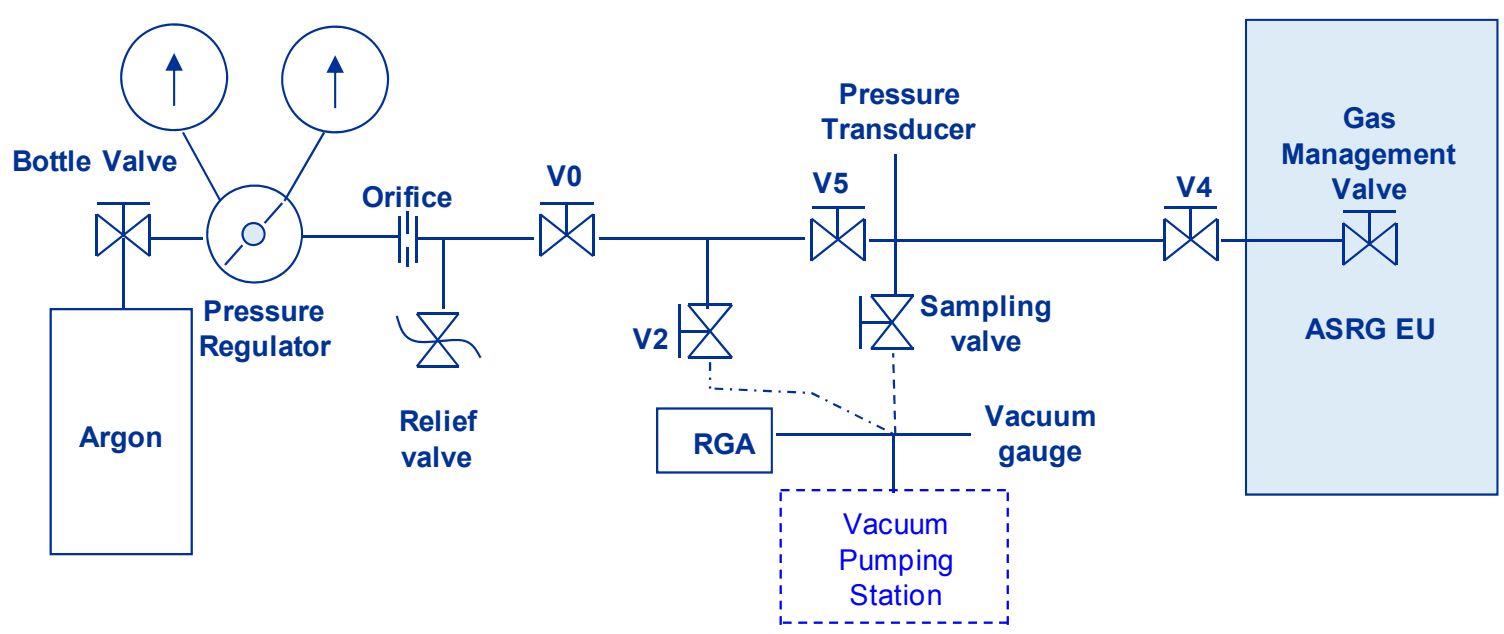

Figure 11.-Argon system schematic. 


\section{Instrumentation, Monitoring, and Safety Systems}

Extensive effort went into designing the instrumentation, monitoring, and safety systems for the test facility. These systems are covered in Reference 8, so they are not discussed in detail in this paper. Instrumentation in the ASRG EU and the test facility includes a variety of sensors to monitor performance of both the EU and the test systems. Some of the sensors in the ASRG EU were installed by LM and delivered with the unit. Where possible, multiple sensors are used to provide redundancy and verification.

Some of the safety systems have already been discussed. The safety systems protect the ASRG EU from potential test system failure modes and abnormal operation and automatically take appropriate corrective action to shut down the ASRG EU in a controlled fashion if necessary.

The LabVIEW (National Instruments) data system monitors critical parameters and will automatically notify the cognizant engineer via a cell phone text message when a parameter exceeds a programmed limit. This allows the engineer to take corrective action in a timely fashion, potentially avoiding a shutdown.

\section{Convertor Control for the ASCs}

The test facility supports two types of convertor control for the ASCs: AC bus control and ACU control. Reference 8 discusses AC bus control in detail. ASRG EU testing began at GRC with AC bus control in part to verify the test facility functionality before transitioning to ACU control.

The ACU (Fig. 12), mounts to the ASRG EU housing, was designed and built by LM (Refs. 1 and 2). Its functions include:

- Controlling the convertors to maximize spacraft power

- Synchronizing the convertors to achieve dynamic balance

- Converting AC output of the convertors to direct-current (DC) power at the spacecraft bus voltage

- Providing telemetry on the ASRG status

- Receiving commands to adjust ASC operating conditions

The ACU uses power electronics to eliminate the need for the tuning capacitors used with AC bus control.

Figure 13 shows the ASRG EU test facility implementation of ACU control. The flight design has the alternator leads connected directly to the power input of the ACU. The ASRG EU test facility includes some modifications. Wires were added to connect the alternator output to a power meter, which measures voltage, current, power, and power factor. A Pearson coil measures current rather than a shunt resistor to avoid adding impedance between the alternator and the ACU. Also, a relay allows the operator or the monitoring system to remove the ACU from the system and shunt the alternator output through an emergency load to stall the convertors. This would be done in the event of a piston overstroke or a loss of control of the convertors. These relays mount to a panel underneath the ASRG EU in the test table. Rather than mount them in the test rack, they were put as close to the EU and ACU as possible to minimize line impedance.

The ACU receives input from the two piston position sensors and several temperature sensors. Some of these sensors are used as control inputs, whereas some are simply used for monitoring.

The test facility uses a Hewlett Packard Model 6060B 300-W DC electronic load set to $28 \mathrm{~V}$, connected across the output of the ACU, in parallel with some capacitance, to simulate the spacecraft DC bus load. The ACU is designed to be compatible with a bus voltage range of 22 to $36 \mathrm{~V}$. At startup, the ACU requires power from the bus. A DC power supply provides startup power at 24 to $26 \mathrm{~V}$ through a diode so that as the ASRG EU heats up and begins to generate power, the power supply output goes to zero. Transducers measure power output from the ACU. With measurement of the power input to the ASRG EU at the heaters, the power between the alternators and the ACU, the power output of the ACU, and the performance and efficiency of the convertors, controller, and EU can be monitored. 


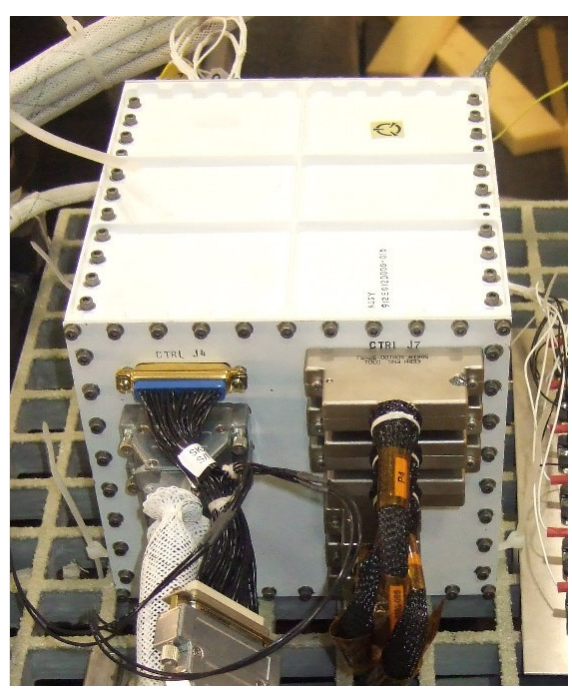

Figure 12.-ASC control unit.

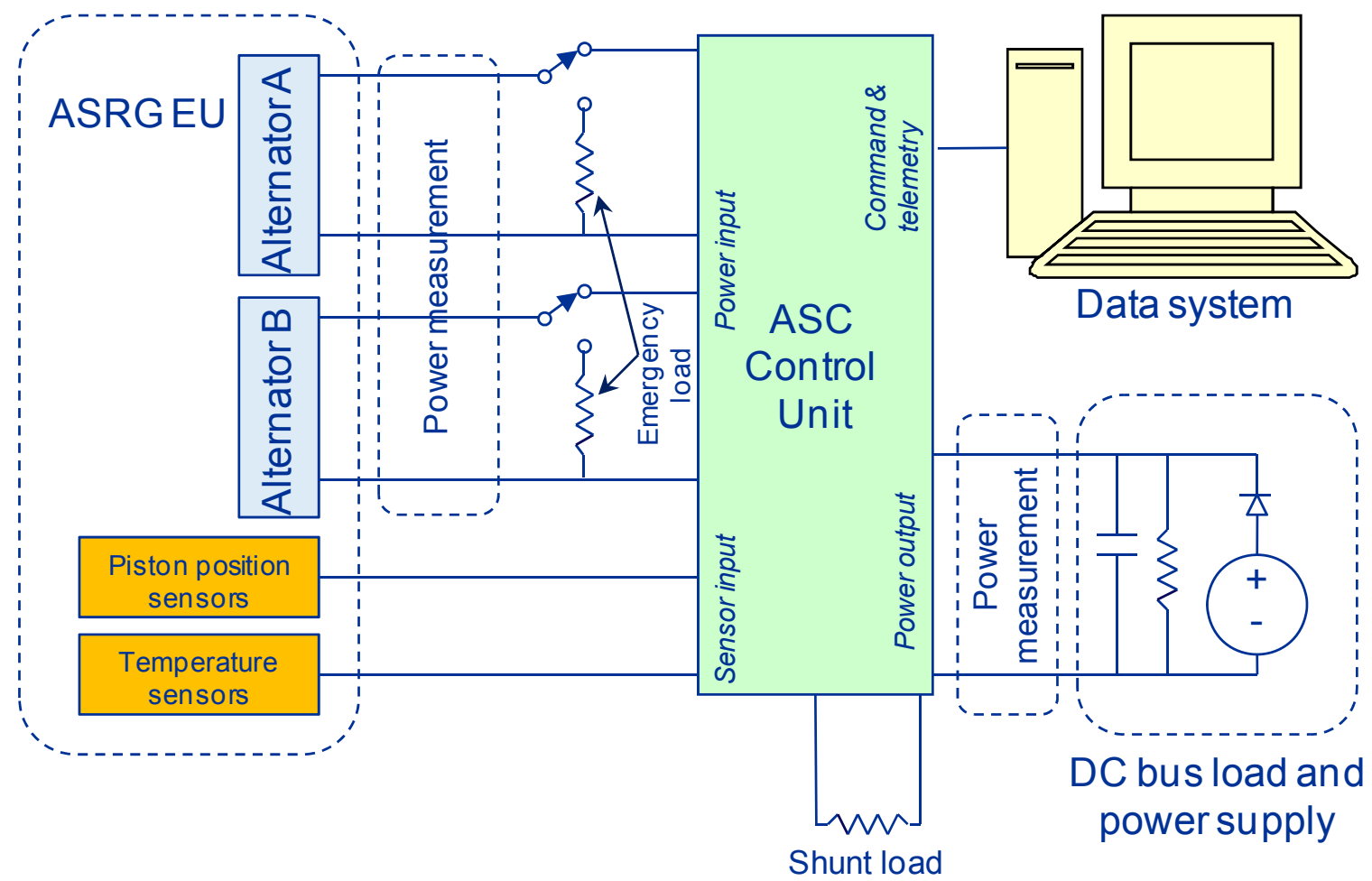

Figure 13.- Simplified schematic of an ACU controller integrated into the ASRG EU test facility.

If the DC bus load becomes disconnected or does not absorb enough of the output power, the ACU sends the power to the shunt load. Although the ASRG EU includes internal shunts for this purpose, separate shunts were mounted in the test rack to use as the shunt load. This avoided the need to design the test facility to handle the heat load from the internal shunts in the unlikely event of loss of DC bus load. Instead the heat would be rejected in the test rack.

The ACU command and telemetry interface utilizes RS-422 serial buses plus some analog signals. The National Instruments LabVIEW system handles the serial communication, allowing the operator to send commands and to continually monitor and display bus parameters. Analog telemetry is interfaced to the LabVIEW analog-to-digital modules and is processed along with other signals. 


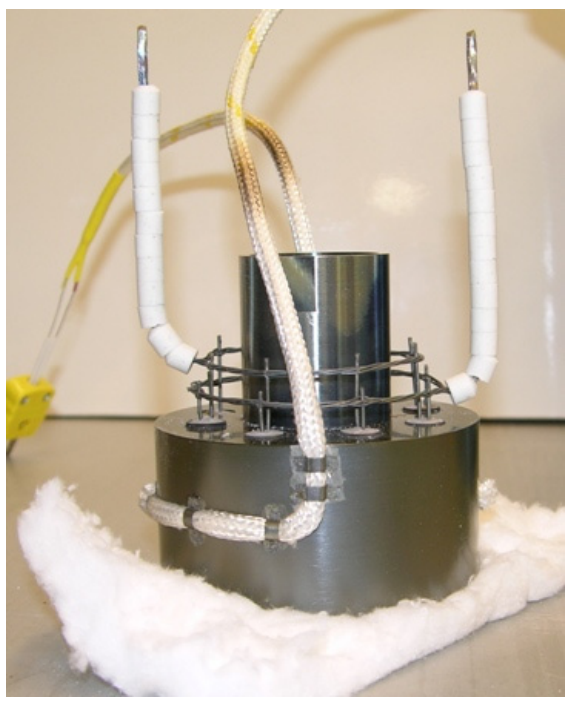

Figure 14.-Cartridge heater heat source designed by GRC and used in the ASRG EU.

\section{Heat Source}

The ASRG EU was tested at LM using an EHS that was dynamically and dimensionally equivalent to a General Purpose Heat Source (GPHS) module (Ref. 2). This was important to obtaining meaningful data from tests like sine transient, random vibration, and shock tests. After internal inspection of the ASRG EU following LM's tests, it was decided to replace the EHS with a cartridge heater furnished by GRC, shown in Figure 14. The EHS had been exposed to significant vibration during testing, and longterm performance was unknown. GRC's extended operation test did not require a heat source dynamically equivalent to the GPHS module, so a drop-in replacement heat source was designed that was based on existing $650{ }^{\circ} \mathrm{C}$ heat sources already proven at GRC's Stirling Research Laboratory. The heat source can provide up to $400 \mathrm{~W}$, with a temperature rise as fast as $1{ }^{\circ} \mathrm{C} / \mathrm{sec}$. This heat source does not impose any limitation on the rate of power reduction. These features allow the ASRG EU to be started up and shut down more quickly than with the EHS. The thermal inertia of the GRC heat source is 36 percent less than that of the EHS, which reduces the hot-end temperature rise in the event of an emergency shutdown of the ASRG EU. This design is expected to have the higher reliability needed for extended operation tests, and to date has demonstrated steady performance with no change in heater resistance.

\section{Heat Source Control}

As mentioned previously, the test facility needed to provide two input power options for the heat source control: (1) fixed hot-end temperature mode, which has been used to date on all extended-operation convertor tests, and (2) fixed heat input mode, which simulates the GPHS module characteristics and tests the temperature-control feature of the ACU. The fixed hot-end temperature mode was implemented by the method used for other test racks at GRC (Ref. 8). For the fixed heat input mode, a controller was designed to monitor each heater's power and adjust the command to each heater power supply.

Figure 15 shows the schematic for the heat source controller. The system consists of an Onset TFX-11 microcontroller, a MAX532 dual channel 12-bit digital-to-analog converter (DAC), and a BPP-440 liquid crystal display. 


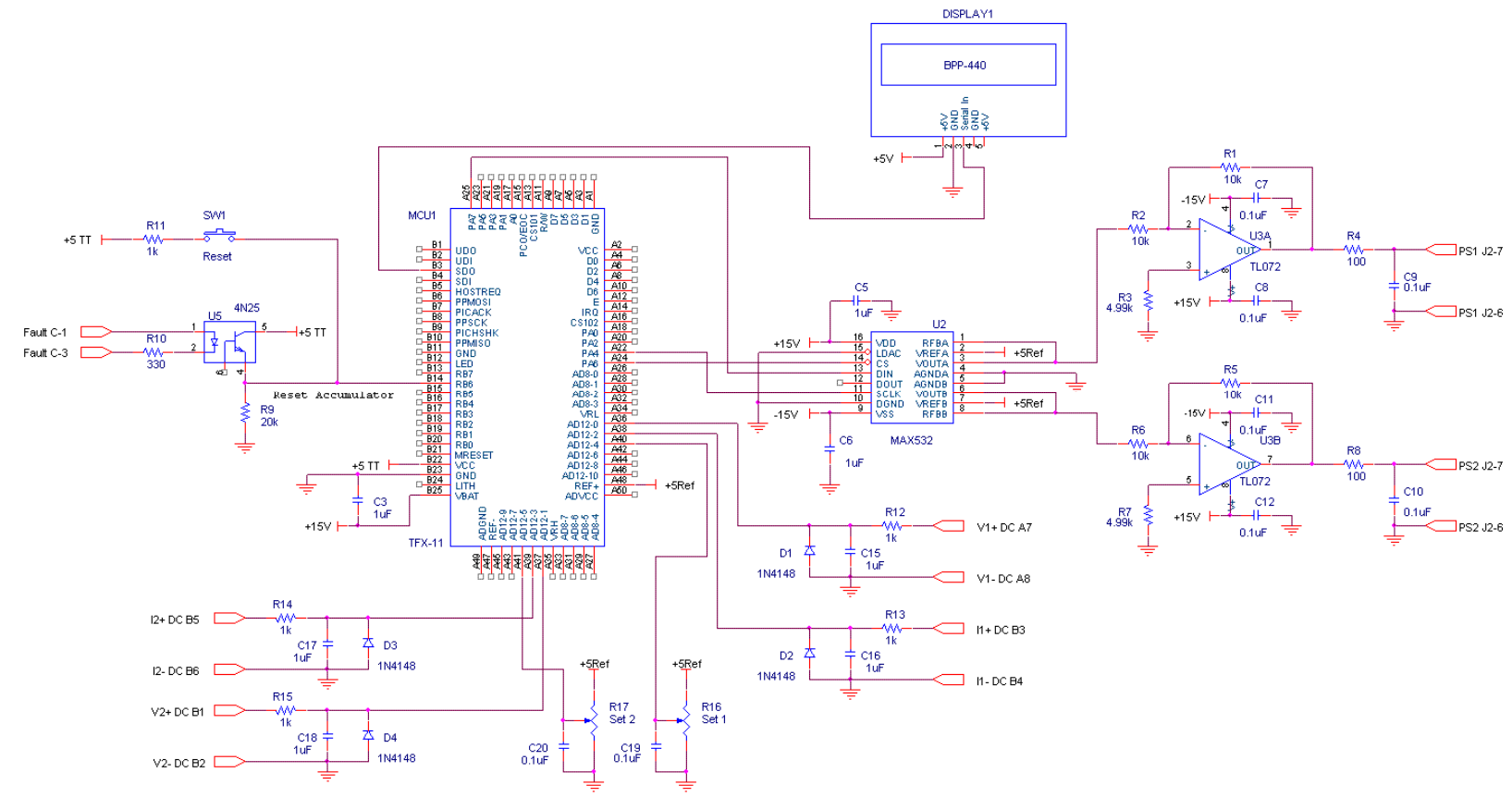

Figure 15.- Heater power controller schematic.

TABLE I.-TEST FACILITY COMPONENT REPLACEMENT INTERVALS

\begin{tabular}{|l|c|}
\hline Component & Planned replacement interval \\
\hline Cooling air fans & 1 to 2 years \\
\hline Auxiliary fans & 1 to 2 years \\
\hline Circulator & 3 to 4 years \\
\hline UPS batteries & Monitor battery temperature \\
\hline
\end{tabular}

In the TFX-11 microcontroller, the control loop begins by reading the voltage and current sensors, the set-point potentiometers, and the fault status. It then calculates the power and resistance of each heater and compares the heater powers to the set points. The proportional-integral-derivative algorithm is then executed for both heaters and the results are limit checked and sent to the DAC. The DAC output is updated with the new values, which are buffered by a dual op-amp and sent to the remote voltage programming pins of the heater power supplies as 0 to $5 \mathrm{~V}$ signals. Finally, the display is updated with the values for the set point, the actual power, the output voltage to the heater power supplies, and the status of the integrator accumulator. The control loop executes at $1 \mathrm{~Hz}$. If the test rack protection system detects a fault condition, the output and set points are immediately set to zero.

\section{Test Facility Maintenance}

Although the ASRG EU was designed for a life exceeding 14 years, many test facility components will not last that long without maintenance or replacement. Certain components will be replaced on a regular basis to reduce the likelihood of unscheduled downtime, as listed in Table I.

The cooling air fans include a speed sensor. Data taken to date have shown a 1 percent decrease in fan speed over 4,000 hr of operation. Although the small decrease in speed is not an issue, it indicates gradual degradation, so the prudent approach involves replacing this low-cost item regularly rather than waiting for a failure.

The circulators used in the ASRG EU test facility have been used for extended operation testing of other convertors in the Stirling Research Laboratory. Typically, they operate at most 4 to 5 years before failure. 


\section{Improvements}

The ASRG-EU was first operated in the test facility under AC bus control on October 28, 2008, with no major problems. After further short-term tests, the EU began 24/7 extended operation on November 6, 2008, and operated continuously until being shut down for a test in February 2009. Although the test facility has met its design requirements, a number of potential improvements were identified during operation. Some improvements have been implemented, and some will be implemented in the future as appropriate.

\section{Heat Rejection System}

The heat rejection system as currently implemented has limited ability to reduce convertor cold-end temperatures more than a few degrees from their current values, and actual cold-end temperatures are running 5 to $10^{\circ} \mathrm{C}$ hotter than the desired operating point of $60^{\circ} \mathrm{C}$. Reducing the circulator temperature from its current setting of 10 to $5^{\circ} \mathrm{C}$ or less would reduce the cold-end temperatures. However, this change would result in more condensation on the lines and elsewhere in the system. Some marginal improvements might be gained by insulating ductwork and better sealing the cage around the EU. The most effective improvement may be to increase the size of the auxiliary cooling fans to improve heat transfer from the EU housing to the air, reducing the temperature difference between the housing and the air.

\section{Components and Connections in the Alternator Load Circuit}

From the beginning of operation, the alternator power and piston amplitude showed anomalous behavior in that these parameters would increase slightly, sometimes very gradually and sometimes rapidly, and then decrease, usually rapidly back to the initial condition. Because the data suggested consistent convertor performance, test rack impedance variation was suspected as the root cause of the anomalous behavior. Simulations and analysis have shown that, for the ASC-E convertors under AC bus control, just a $3-\mathrm{m} \Omega$ increase in impedance would result in a $0.01-\mathrm{mm}$ increase in piston amplitude and a corresponding increase in power. With the load circuit containing numerous connectors, relays, and other components, it is plausible that a variety of causes could result in a several milliohm change in impedance (see Fig. 5 of Ref. 8). A number of dynamic simulations were run, and the results showed that, for example, a particular change in amplitude and power observed in the test data was consistent with a $35-\mathrm{m} \Omega$ change in impedance between the power meter and the load resistor.

In March 2009 a number of improvements were made to connections in the load circuit to address this problem. After the ASRG EU was restarted, the magnitude of the anomalous behavior was reduced but not eliminated. In July 2009 additional improvements were made, including using a soldered bus bar for tuning capacitor bank connections and temporarily eliminating two relays. These test rack improvements appear to have resolved the anomalous behavior. A hermetically-sealed relay is currently being tested as a possible replacement for the suspect relays in the load circuit.

\section{Summary}

A test facility was designed and built for extended-operation testing of the Advanced Stirling Radioisotope Generator Engineering Unit (ASRG EU). The facility allows for heat input under both fixed-temperature and fixed-power modes. The EU can be operated with either AC bus control or ACU control. Safety features allow 24/7 unattended operation, with call-home features notifying engineers of any deviations in critical parameters. Performance to date has shown that the test facility has met its design requirements, although a few areas for improvement have been identified. 


\section{References}

1. Chan, J., Wood, J.G., and Schreiber, J.G., "Development of Advanced Stirling Radioisotope Generator for Space Exploration," Proceedings of Space Technology and Applications International Forum (STAIF 2007), edited by M.S. El-Genk, AIP Conference Proceedings 880, pp. 615-623, 2007.

2. Chan, J., Hill, D., Hoye, T, and Leland, D., "Development of Advanced Stirling Radioisotope Generator for Planetary Surface and Deep Space Missions," Proceedings of the Sixth International Energy Conversion Engineering Conference (IECEC 2008) American Institute for Aeronautics and Astronautics, 2008.

3. Cornell, P.A., Lewandowski, E.J., Oriti, S.M., and Wilson, S.D., "Stirling Convertor Extended Operation Testing and Data Analysis at NASA Glenn Research Center," Proceedings of the Seventh International Energy Conversion Engineering Conference (IECEC 2009) American Institute for Aeronautics and Astronautics, 2009.

4. Lewandowski, E.J., Schreiber, J.G., Wilson, S.D., Oriti, S.M., Cornell, P, and Schifer, N., "Extended Operation Testing of Stirling Convertors in Support of Stirling Radioisotope Power System Development," Proceedings of the Sixth International Energy Conversion Engineering Conference (IECEC 2008) American Institute for Aeronautics and Astronautics, 2008.

5. Oriti, S.M. and Cornell, P.A., "Processing and Preparation of Advanced Stirling Convertors for Extended Operation at NASA Glenn Research Center," Proceedings of the Sixth International Energy Conversion Engineering Conference (IECEC 2008) American Institute for Aeronautics and Astronautics, 2008.

6. Schreiber, J.G., "Summary of Stirling Convertor Testing at GRC," Proceedings of the Fourth International Energy Conversion Engineering Conference (IECEC 2006) American Institute for Aeronautics and Astronautics, 2006.

7. Roth, M.E., Schreiber, J.G., and Pepper, S.V., "Extended Operation of Stirling Convertors," Proceedings of the Second International Energy Conversion Engineering Conference (IECEC 2004) American Institute for Aeronautics and Astronautics, 2004; NASA/TM-2004-213388.

8. Dugala, G., "Test Rack Development for Extended Operation of Advanced Stirling Convertors at NASA Glenn Research Center," Proceedings of the Seventh International Energy Conversion Engineering Conference (IECEC 2009) American Institute for Aeronautics and Astronautics, 2009. 


\begin{tabular}{|c|c|c|}
\hline \multicolumn{2}{|c|}{ REPORT DOCUMENTATION PAGE } & $\begin{array}{l}\text { Form Approved } \\
\text { OMB No. 0704-0188 }\end{array}$ \\
\hline \multicolumn{3}{|c|}{ 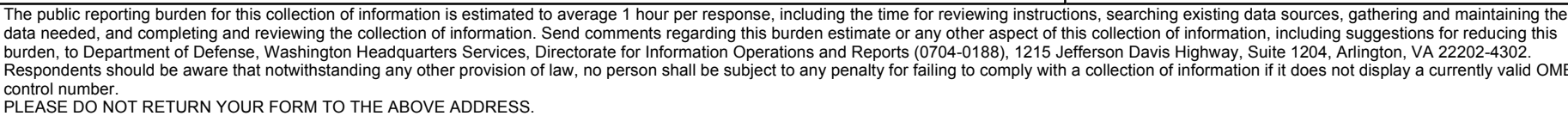 } \\
\hline $\begin{array}{l}\text { 1. REPORT DATE (DD-MM-YYYY) } \\
01-08-2010\end{array}$ & $\begin{array}{l}\text { 2. REPORT TYPE } \\
\text { Technical Memorandum }\end{array}$ & 3. DATES COVERED (From - To) \\
\hline \multirow{3}{*}{\multicolumn{2}{|c|}{$\begin{array}{l}\text { 4. TITLE AND SUBTITLE } \\
\text { Design of a Facility to Test the Advanced Stirling Radioisotope Generator Engineering U }\end{array}$}} & 5a. CONTRACT NUMBER \\
\hline & & 5b. GRANT NUMBER \\
\hline & & 5c. PROGRAM ELEMENT NUMBER \\
\hline \multirow{3}{*}{\multicolumn{2}{|c|}{$\begin{array}{l}\text { 6. AUTHOR(S) } \\
\text { Lewandowski, Edward, J.; Schreiber, Jeffrey, G.; Oriti, Salvatore, M.; Meer, David, W.; } \\
\text { Brace, Michael, H.; Dugala, Gina }\end{array}$}} & 5d. PROJECT NUMBER \\
\hline & & 5e. TASK NUMBER \\
\hline & & $\begin{array}{l}\text { 5f. WORK UNIT NUMBER } \\
\text { WBS } 138494.04 .01 .01\end{array}$ \\
\hline \multicolumn{2}{|c|}{$\begin{array}{l}\text { 7. PERFORMING ORGANIZATION NAME(S) AND ADDRESS(ES) } \\
\text { National Aeronautics and Space Administration } \\
\text { John H. Glenn Research Center at Lewis Field } \\
\text { Cleveland, Ohio 44135-3191 }\end{array}$} & $\begin{array}{l}\text { 8. PERFORMING ORGANIZATION } \\
\text { REPORT NUMBER } \\
\text { E-17319 }\end{array}$ \\
\hline \multirow{2}{*}{\multicolumn{2}{|c|}{$\begin{array}{l}\text { 9. SPONSORING/MONITORING AGENCY NAME(S) AND ADDRESS(ES) } \\
\text { National Aeronautics and Space Administration } \\
\text { Washington, DC 20546-0001 }\end{array}$}} & $\begin{array}{l}\text { 10. SPONSORING/MONITOR'S } \\
\text { ACRONYM(S) } \\
\text { NASA }\end{array}$ \\
\hline & & $\begin{array}{l}\text { 11. SPONSORING/MONITORING } \\
\text { REPORT NUMBER } \\
\text { NASA/TM-2010-216742 }\end{array}$ \\
\hline \multicolumn{3}{|c|}{$\begin{array}{l}\text { 12. DISTRIBUTION/AVAILABILITY STATEMENT } \\
\text { Unclassified-Unlimited } \\
\text { Subject Category: } 20 \\
\text { Available electronically at http://gltrs.grc.nasa.gov } \\
\text { This publication is available from the NASA Center for AeroSpace Information, 443-757-5802 }\end{array}$} \\
\hline
\end{tabular}

\section{SUPPLEMENTARY NOTES}

\section{ABSTRACT}

The Advanced Stirling Radioisotope Generator (ASRG), a high efficiency generator, is being considered for space missions. An engineering unit, the ASRG engineering unit (EU), was designed and fabricated by Lockheed Martin under contract to the Department of Energy. This unit is currently under extended operation test at the NASA Glenn Research Center (GRC) to generate performance data and validate the life and reliability predictions for the generator and the Stirling convertors. A special test facility was designed and built for the ASRG EU. This paper summarizes details of the test facility design, including the mechanical mounting, heat-rejection system, argon system, control systems, and maintenance. The effort proceeded from requirements definition through design, analysis, build, and test. Initial testing and facility performance results are discussed.

\section{SUBJECT TERMS}

Advanced Stirling Radioisotope Generator; High efficiency generators; Stirling convertors; Radioisotope power systems

\begin{tabular}{|c|c|c|c|c|c|}
\hline \multicolumn{3}{|c|}{ 16. SECURITY CLASSIFICATION OF: } & \multirow{2}{*}{$\begin{array}{l}\text { 17. LIMITATION OF } \\
\text { ABSTRACT } \\
\text { UU }\end{array}$} & \multirow{2}{*}{$\begin{array}{l}\text { 18. NUMBER } \\
\text { OF } \\
\text { PAGES } \\
20\end{array}$} & \multirow{2}{*}{$\begin{array}{l}\text { 19a. NAME OF RESPONSIBLE PERSON } \\
\text { STI Help Desk (email:help@ } \text { sti.nasa.gov) } \\
\text { 19b. TELEPHONE NUMBER (include area code) } \\
\text { 443-757-5802 }\end{array}$} \\
\hline $\begin{array}{l}\text { a. REPORT } \\
U\end{array}$ & $\begin{array}{l}\text { b. ABSTRACT } \\
U\end{array}$ & $\begin{array}{l}\text { c. THIS } \\
\text { PAGE } \\
\text { U }\end{array}$ & & & \\
\hline
\end{tabular}



